\title{
Notes on the vocalizations of Rufous-winged Antwren (Herpsilochmus rufimarginatus)
}

\author{
Peter Boesman
}

In the following we briefly analyze and compare voice of the different races of Rufous-winged Antwren (Herpsilochmus rufimarginatus). We also try to quantify the extent of any vocal differences using the criteria proposed by Tobias et al. (2010), as a support for taxonomic review. We have made use of sound recordings available on-line from Xeno Canto (XC).

Loudsong is a stuttering series of notes, accelerating towards the end. We have made a number of measurements for the basic sound parameters of this loudsong:






\section{HANDBOOK OF THE wirof Alve}

\section{ORNITHOLOGICAL NOTES}

Song of all races is very similar except nominate race. Race scapularis of NE Brazil surprisingly is in the same group as frater and exiguus. This is assuming that scapularis occurs only south to S Alagoas, while birds further south are nominate (different from HBW Vol. 8 !).

It is clear from the above measured parameters that race rufimarginatus differs in many ways (Fig. 1):

song initiates with typically 3 slow-paced notes (score 3-4) which rise in frequency (score 2) reaching a higher frequency than other races (score 3), after which a low number of fast notes gradually decelerate. Total number of notes is lower (score 1-2) and overall song length is marginally longer, resulting in a much lower average pace (score 2-3).

Also, song of other races switches halfway to much more scratchy notes.

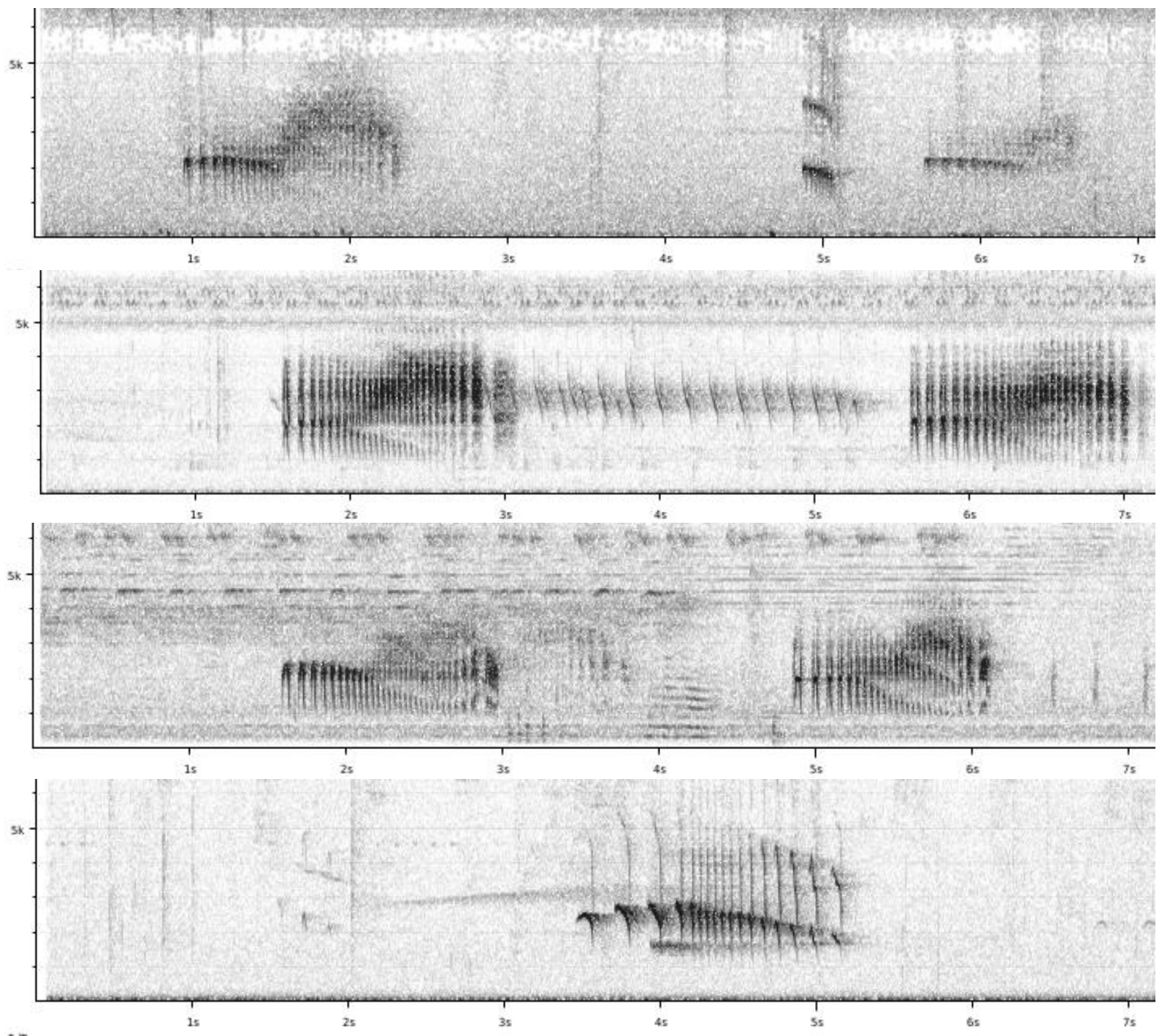

Figure 1: top to bottom: typical loudsong of exiguus, frater, scapularis and rufimarginatus

Furthermore, call seems to differ significantly as well, with nominate typically uttering short series of 2-5 mellow notes repeatedly. 

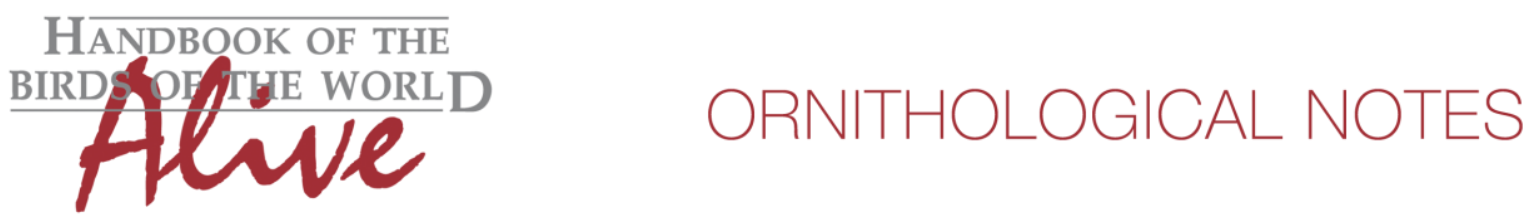

We can conclude that vocal differences of race rufimarginatus vs. all other races are significant, leading to a total score of about 6.

At the other hand, differences between the 3 other races are minimal, with almost all data ranges overlapping. Score at most $1+1$.

This note was finalized on 18th June 2015 , using sound recordings available on-line at that moment. We would like to thank in particular the many sound recordists who placed their recordings for this species on XC.

\section{References}

Tobias, J.A., Seddon, N., Spottiswoode, C.N., Pilgrim, J.D., Fishpool, L.D.C. \& Collar, N.J. (2010). Quantitative criteria for species delimitation. Ibis 152(4): 724-746.

Zimmer, K., Isler, M.L. (2003). Rufous-winged Antwren (Herpsilochmus rufimarginatus). In: del Hoyo, J., Elliott, A., Christie, D.A. (eds.). Handbook of the Birds of the World Vol. 8. Broadbills to Tapaculos. Lynx Edicions, Barcelona.

\section{Recommended citation}

Boesman, P. (2016). Notes on the vocalizations of Rufous-winged Antwren (Herpsilochmus rufimarginatus). HBW Alive Ornithological Note 50. In: Handbook of the Birds of the World Alive. Lynx Edicions, Barcelona. (retrieved from http://www.hbw.com/node/931929 on 29 April 2016). 